\title{
Catholic Presence and Power: Jesuit Painter Bernardo Bitti at Lake Titicaca in Peru
}

\author{
Christa Irwin \\ Marywood University \\ irwin@marywood.edu
}

\begin{abstract}
Bernardo Bitti was an Italian Jesuit and painter who traveled to the viceroyalty of Peru at the end of the sixteenth century to make altarpieces in the service of the order's conversion campaigns. He began his New World career in Lima, the viceregal capital and then, over a span of thirty-five years, traveled to Jesuit mission centers in cities throughout Peru, leaving a significant imprint on colonial Peruvian painting. In 1586, Bitti was in Juli, a small town on Lake Titicaca in southern Peru, where the Jesuits had arrived a decade prior and continually faced great resistance from the local population. In this paper, I will argue that Bitti's paintings were tools implemented by the Jesuit missionaries seeking to establish European, Christian presence in the conflicted city. Thus, Bitti's contribution at Juli can serve as but one example of how the Jesuits used art as part of their methodology of conversion.
\end{abstract}

\section{Keywords}

Jesuit - Bernardo Bitti - Juli - Peru - missions - colonial painting - viceroyalty - Lake Titicaca

In 1576, a small group of Jesuits arrived at the town of Juli in the south of Peru. After a failed attempt by an earlier set of missionaries, and significant hesitancy on the part of the Jesuits the evangelization efforts at Juli would eventually come to mark an example of success for other Jesuit sites. Juli presents a fascinating case of Jesuit mission activity because it offers documentation of the indigenous culture's integration into a newly created Christian town. At the core was the mission, to convert the Andean people, by the order of God

(C) CHRISTA IRWIN, $2019 \mid$ DOI:10.1163/22141332-00602005

This is an open access article distributed under the terms of the prevailing CC-BY-NC license at the time of publication. 
and, by the order of the viceroy and the king of Spain. Among the missionaries working at Juli were some strong voices, speaking for the rights and humanity of the Andean people. José de Acosta (1540-16oo) sought ways to cut through the disparate segregation that culture, language, and geography had forged over the centuries. Blas Valera (1545-97), a mestizo Jesuit priest, argued for the life and rights of the Andean people, and even got on his knees to plead with the viceroy for the pardon of Tupac Amaru (r.1571-72), the last Inca king. The Jesuit consideration of local life and belief is evident in many aspects of Juli's history; the town's four churches were organized according to the prehispanic division of the city into Hanan and Hurin, concepts that referred to upper and lower halves of a duality understood in many Andean cultures, and that were often applied to social divisions in towns and villages. ${ }^{1}$ Juli was at the center of an overwhelmingly indigenous region of the viceroyalty, which remained as such well into the eighteenth century, and marked a spot on a major trading route. ${ }^{2}$ Therefore, Juli was a kind of focal point of indigenous culture, and also of local art and craft. Textiles made by local craftsmen were inventoried in the churches as early as 1560 and by the last quarter of the seventeenth century, that indigenous presence became visually evident in the architecture of Juli, particularly in carved facades, doorways, and interiors. ${ }^{3}$ While imposing Christianity, the Jesuits did not force the complete destruction of Andean culture, but instead utilized their knowledge of local life to aid in their own efforts to teach Christianity. There was, simultaneously, a campaign to introduce European, Christian culture. The Italian painter, Bernardo Bitti (1548-1610), one of the viceroyalty's most well-known European transplants, made several visits to Juli between 1585 and 1586 and then once more in 1602 , to complete at least five paintings. Bitti was a tool, used by the Jesuit missionaries to represent Europe and Christianity. It is compelling to consider how his paintings fit into the larger context of the town. In a general sense, Bitti's paintings, like so many others in colonial Latin America that were made in a style closely imitating the European Renaissance and Baroque, offered what the missionaries believed was important and inspiring in the Old World aesthetic. Chroniclers of mission

1 Gauvin Alexander Bailey, The Andean Baroque: Convergent Cultures in the Churches of Colonial Peru (Notre Dame, IN: Notre Dame University Press, 2010), 165-70.

2 Maya Stanfield-Mazzi, Object and Apparition: Envisioning the Christian Divine in the Colonial Andes (Tucson: The University of Arizona Press, 2013), 38-49. See Stanfield-Mazzi for a helpful discussion of the cultural, religious, and artistic situation in this area prior to and upon the arrival of the Spanish.

3 Stanfield-Mazzi, Object and Apparition, 45-47; Bailey, Andean Hybrid Baroque, 163-97. Bailey's chapter on Juli examines this architectural decoration in great detail. 
activities relayed legends of chiefs or kings being moved to conversion in front of a European painting, so taken by its illusionism that they believed the truth of its message. ${ }^{4}$ As one of the viceroyalty's most experienced painters, Bitti must have arrived at Juli with the task of creating such an example, perhaps one of these visual miracles.

Of course, the narrative of sacred painting's power to bring one to his knees and see the light of God is not a new one, and the situation of Bitti's paintings at Juli is not necessarily different from any other. While valid and certainly a significant component of Bitti's job at Juli, there are more questions to ask. This article will examine the details of the mission at Juli, and Bitti's work, as a case study of how paintings by a European artist might have functioned in their context, beyond the oft repeated legend of divine inspiration through painting.

The visual arts played a significant role in the evangelization efforts on the missions in colonial Latin America. Perhaps most directly, painting and sculpture had the potential to break through the language barriers that inhibited the communication of the Christian faith's tenets and beliefs. According to Christian missionaries the visual arts could also be used as powerful tools for conversion; art could move and inspire. Art and Christianity have had a powerful relationship throughout the history of the faith; it is not surprising to see that link travel with the European missionaries of the sixteenth and seventeenth centuries. And, travel it did. Art itself made the journey across the ocean to the New World, in great quantities. Paintings, sculptures, prints, and books were sent to Mexico and Peru to instruct and inspire. Artists travelled as well, from Spain, Flanders, and Italy to Mexico City and Lima to contribute art to the new churches of the Spanish viceroyalties. Like so many other tools used by the Spanish, works of art functioned as part of the mechanics of colonization. Objects and artists were imported in order to impose a new aesthetic vision that paired with a new belief system. An artist like Bernardo Bitti served as a representative of European, and specifically, Roman, culture. The initial influx of European art and artists was calculated. ${ }^{5}$ In addition to narrative and iconography, Western art introduced Western aesthetics, and countered the local traditions, particularly in the introduction of art as illusion. A number of

4 Gauvin Alexander Bailey, Art on the Jesuit Missions in Asia and Latin America 1542-1773 (Toronto: University of Toronto Press, 1999), 33-35. See also Samuel Edgerton, The Renaissance Rediscovery of Linear Perspective (New York: Basic Books, Inc., Publishers, 1975), 12-15.

5 See Ananda Cohen-Suarez, "Decolonizing the Global Renaissance: A View from the Andes," in The Globalization of Renaissance Art: A Critical Review, ed. Daniel Savoy (Leiden: Brill, 2017), 67-94, here 71-73, for a conversation about considering how Western art was imposed upon indigenous populations. 
scholars have discussed this collision of visual traditions. Gauvin Bailey makes only brief mention of this idea in his study of art on the Jesuit missions, and Samuel Edgerton offers some discussion of Renaissance illusionism's magic as it might have been perceived by non-European cultures in his study of linear perspective. ${ }^{6}$ Edgerton asserts that while there is no evidence to suggest that the missionary friars had any interest in teaching linear perspective to indigenous artists its own sake, but did, it seems, rely on the illusion offered by its effects. Perspective is but one quality that set European art apart from the so-called idols of the Andean cultures encountered by the Christians. More research needs to be done to better understand what missionaries believed examples of European art might offer in this context. Bitti's paintings at Juli can serve as one set of examples.

Although all of the Christian orders active in the New World utilized painting, sculpture, and architecture to communicate and inspire, it was the Jesuits who most emphatically supported the visual arts as a tool for the purposes of evangelization and conversion. Scholars have offered compelling evidence to suggest just how integral art was to the Jesuit missions and just how unique the Jesuit approach to the use of art was, among all of the other active Christian orders, but more could be said of how individual objects might have been used and understood. ${ }^{7}$ More examples will further our understanding of the relationship forged between the Jesuits, the art they made and used on the missions, and the indigenous populations who saw it. It is here that Juli becomes an ideal opportunity for research. All four churches used by the Jesuits at Juli were filled with paintings, sculptures, and elaborate retablos (altarpieces). A potential wealth of information about Jesuit art remains in this remote southern Peruvian town.

\section{Bernardo Bitti}

The art that emerged from colonial Latin American Jesuit mission sites has often been referred to as "hybrid" to reflect the culmination of interactions

6 Samuel Edgerton, Theaters of Conversion: Religious Architecture and Indian Artisans in Colonial Mexico (Albuquerque: University of New Mexico Press, 2001), 139-42.

7 John W. O'Malley et al., The Jesuits: Cultures, Sciences and the Arts, 1540-1773 (Toronto: University of Toronto Press, 1999); Bailey, Art on the Jesuit Missions; John W. O'Malley et al., The Jesuits II: Cultures, Sciences and the Arts, 1540-1773 (Toronto: University of Toronto Press, 2000); John W. O'Malley et al., The Jesuits and the Arts, 1540-1773 (Philadelphia: St. Joseph's University Press, 2006). 
between European Christian culture, style, and iconography, and components of indigenous traditions that the missionaries deemed reasonable, appropriate, and useful. Local artists also made a considerable impact on colonial art because of their sustained involvement in artmaking. ${ }^{8}$ Bernardo Bitti's paintings at Juli are not "hybrid" in and of themselves as objects. They are paintings made in an Italian style by an Italian artist, according to iconographic standards of the Roman Catholic Church. However, they need to be regarded as objects made in South America, for a largely Andean audience. Investigating Bitti's paintings at Juli then is not a task that involves locating European and indigenous sources but considering how European art might have been used and received in this South American context.

Bernardo Bitti was among the most influential of European artists working in colonial South America, a Jesuit himself, trained in Italy, and originally from the Marche region in Camerino. ${ }^{9}$ Born in 1548 , Bitti joined the Jesuit order in 1568 , at which point he traveled to Rome. Unfortunately, very little is known of

8 Despite the frequent and common usage of the term "hybridity" in this context, it is not without difficulty that I introduce it here. Carolyn Dean and Dana Liebsohn critiqued its usage most sufficiently in their 2003 article. As the authors make clear with archival examples from colonial episodes, there is no evidence to suggest that seventeenth- and eighteenth-century viewers would necessarily have pulled apart the cultural sources of the art we are attempting to label as hybrid. See Carolyn Dean and Dana Liebsohn, "Hybridity and Its Discontents: Considering Visual Culture in Colonial Latin America," Colonial Latin American Review 12, no. 1 (January, 2003): 5-35.

9 Several South American scholars and a few notable American scholars have contributed important scholarship about Bitti. José de Mesa and Teresa Gisbert, Bernardo Bitti (La Paz: Biblioteca de Arte y Cultural Boliviana and Dirección Nacional de Informaciones de la Presidencia de la Republica, 1961); José de Mesa and Teresa Gisbert, Bitti, un pintor manierista en Sudamérica (La Paz: Universidad Mayor de San Andrés, 1974); José de Mesa and Teresa Gisbert, Historia de la pintura cuzqueña (Buenos Aires: Instituto de Arte Americano e Investigaciones Estéticas, 1962); Francisco Stastny, El manierismo en la pintura colonial latinoamericana (Lima: Universidad Nacional Mayor de San Marcos, 1981); José Chichizola Debernardi, El manierismo en lima (Lima: Pontifica Universidad Católica del Perú, 1983), 107-11; Damián Bayón and Murillo Marx, History of South American Colonial Art and Architecture: Spanish South America and Brazil (New York: Rizzoli, 1989), 105; George Kubler and Martin Soria, Art and Architecture in Spain and Portugal and Their American Dominions, 1500-1800 (Baltimore: Penguin Books, 1959), 321-22; Gauvin Alexander Bailey, "Creating a Global Artistic Language in Late Renaissance Rome: Artists in the Service of the Overseas Missions, 1542-1621," in From Rome to Eternity: Catholicism and the Arts in Italy, ca.1550-1650, ed. Pamela Jones and Thomas Worcester (Leiden: Brill, 2002), 226-48. 
Bitti's early years and his time in Europe. ${ }^{10}$ By 1573 , Bitti was in Seville, and two years later in Lima, where he was immediately put to work on several retablos (altarpieces) for the Jesuit church of San Pablo in the viceroyalty's capital. ${ }^{11}$ After eight years in Lima, the Jesuits began sending Bitti to mission locations throughout the far reaches of the viceroyalty, including Cusco, Arequipa, La Paz, Sucre, Huamanga, and Juli. ${ }^{12}$ At Juli, he designed retablos and paintings, and helped to establish an indigenous carpentry workshop. ${ }^{13}$ Documents charting Bitti's time in Juli are sparse; there are orders from the current viceroy, García Hurtado de Mendoza (1535-16o9), that the retablos for Juli be completed by 1592, and a document from 1584 , written by a rector at Juli to Claudio Acquaviva, Jesuit superior general in Rome, indicates that Bitti would paint six works over the course of two months. ${ }^{14}$ Additional documentation specifically mentioning Bitti, however, is lacking. Therefore, assessing Bitti's contributions in any kind of precise manner is challenging; renovations to and reconfiguration of churches have also added a layer of distance from the original artistic contributions at Juli. The churches at Juli housed visual art objects from their inception; a visita (official church report) from 1560 reported altars, baptismal fonts, painted images, and textiles in all of the town's churches. ${ }^{15}$ The textiles were made by local Andean artists and used to cover the church's liturgical structures, the paintings were imported or made by friar-artists. Over time, Juli came to be known as the "Rome of the Andes," because of its churches' lavish decoration in painting and sculpture. One is left wondering who contributed all these many works of art, over what timeline, according to what program, and how those objects functioned in the daily life of the town's population.

In 1767 , there was a vast inventory conducted of all four Juli churches, by the Junta de Temporalidades. ${ }^{16}$ The inventory is detailed with regard to the subject matter and placement of paintings and sculptures, and makes clear that Juli's churches were in fact highly ornamented with various types of visual arts. Five

10 See Christa Irwin, "Roma in Lima: Italian Renaissance Influence in Colonial Peruvian Painting” (PhD diss., CUNY Graduate Center, 2014) for a much more complete discussion of what can be assessed of Bitti's background and formation as an artist.

Although Bitti has most often been cited as a painter and most of the scholarship on Bitti focuses on his paintings, he was also a sculptor and collaborated with the Jesuit artist, Pedro de Vargas on a number of polychrome sculptures for churches in Lima and other Peruvian cities.

12 Mesa and Gisbert, Bitti, pintor, 48.

13 Bailey, Andean Hybrid Baroque, 167.

14 Bailey, Andean Hybrid Baroque, 167.

15 Stanfield-Mazzi, Object and Apparition, 43-44.

16 Stanfield-Mazzi, Object and Apparition, 174. 
paintings can be fairly securely attributed to Bitti through stylistic analysis: Holy Family (Figure 5.1), Baptism of Christ (Figure 5.2), Saint John the Baptist (Figure 5.3), Saint Catherine (Figure 5.4), and Saint Margaret.

The ${ }^{1767}$ inventory of paintings at Juli's four churches does not mention the artists' names, but the documentation does make note of paintings designated as "Roman," which several scholars have agreed likely refers to works made by Bitti or his followers. ${ }^{17}$ The inventory's notation of "Roman" for certain paintings must reflect either a consistent and recognizable style and/or a designation inscribed on the work of art itself. Either way, the paintings associated with Bitti were distinguished from all others that decorated the churches in the eighteenth century, and probably received distinct attention in the sixteenth century as well.

This poses the inevitable question of why there might have been a desire for anything "Roman" in the small mission town of Juli at the end of the sixteenth century. The answer lies in concerns beyond the local scope of southern Peru. In a global sense, Rome represented the center of the Catholic Church, and at the end of the sixteenth century, the Catholic Reformation. ${ }^{18}$ Spurred by the campaigns of the reform movement and the dictates of the Council of Trent, artists made necessary renovations to Catholic art in the late Renaissance. Although the council addressed issues of sacred art only briefly, its decrees had a significant impact on artists and patrons. ${ }^{19}$ Responses varied, but all focused to a certain degree on the need for art to be arte sacra (sacred art), art that was made for and promoted sacred devotions. ${ }^{20}$ The extensive archives of the Jesuits provide evidence of how Rome communicated these and other ideas with

17 Bailey, Andean Hybrid Baroque, 175; Ramon Gutiérrez, Arquitectura del altiplano peruano (Chaco: Universidad Nacional del Nordeste, 1979), 331.

18 There is some sense that Roman presence in the viceroyalties also created some connection to the imperial past of the ancient city. See Alejandra Osorio, Inventing Lima:Baroque Modernity in Peru's South Sea Metropolis (New York: Palgrave Macmillan, 2008), 12-13; and Anthony Pagden, Lords of all the World: Ideologies of Empire in Spain, Britain and France, c.1500-180o (New Haven: Yale University Press, 1995), 19-20; and Alfonso Ortiz Crespo, "The Spanish American Colonial City: Its Origins, Development, and Functions," in The Arts in Latin America, 1492-1820 (Philadelphia: Philadelphia Museum of Art, 2006), 23-29, here 23 .

19 James Waterworth, trans., Canons and Decrees of the Sacred and Oecumenical Council of Trent (London: C. Dolman, 1848), 234.

20 Peter Burke, "Rome as Center of Information and Communication for the Catholic World, 1550-1650," in From Rome to Eternity, ed. Jones and Worcester, 256-65. 
missions around the world. ${ }^{21}$ Much of the art made by European artists working for overseas missions, conformed in many ways to the expectations of arte sacra. Paintings are simple, bright, and clear, with little extraneous narrative.

This is the case for Bitti's paintings at Juli. An example is his Holy Family (Figure 5.1), in the church of San Pedro. The composition is tightly focused on the Virgin and Child, centrally placed, with Joseph to their left. Bitti did not clutter the painting with nonessential figures or attributes. The Virgin is demure and humble, gazing down past the child, rather than straight out at the viewer. Duly in line with late-sixteenth-century expectations, Bitti's style, which in the past has been generally categorized as "Mannerist" is in fact a reconciliation of the continued taste for Mannerism's refined formal elegance with the need for reform promoted in the post-Tridentine climate. ${ }^{22}$ Thus, in contrast to the paintings often called Mannerist in Europe (and of course the term itself is challenging and complex because of its multiple meanings and usages), Bitti's painting lacks the erudition, the elitism, and the erotic veil that garnered so much criticism in the middle of the sixteenth century in Europe. Ultimately, the clear, direct compositions and bright uncomplicated narrative of the Holy Family, and all of Bitti's known Juli paintings are in line with postTridentine art of the late sixteenth century. ${ }^{23}$ Bitti's painting represented European standards in Catholic art.

21 Burke, "Rome as Center of Information," 263. Here Burke cites ideas written by Giovanni Botero, Relations, of the Most Famous Kingdoms and Commonwealths through the World: Discoursing of Their Situations, Manners, Customs, Strengths, Greatness, and Policies (London: Adam Islip, 1610).

22 The earliest scholars to discuss Bitti labeled him as a Mannerist artist and did not take their analysis beyond. Included among those scholars are George Kubler and Martin Soria, Art and Architecture in Spain and Portugal and their American Dominions, 1500-1800 (Baltimore: Penguin Books, 1959), 321-22, and Mesa and Gisbert, Bitti. In his El manierismo en la pintura colonial latinoamericana (Lima: Universidad Nacional Mayor de San Marcos, 1981), Francisco Stastny suggested a need for a more nuanced analysis of Bitti's style, considering their location outside of the European context. José Chichizola Debernardi, El manierismo en Lima (Lima: Pontifica Universidad Catolica del Perù, 1983) catalogues the phenomenon of art that replicates the style often called Mannerism in Europe.

23 This is a topic of much complexity, and one that scholars have often wrestled with. Two good sources are: Gauvin Alexander Bailey, Between Renaissance and Baroque: Jesuit Art in Rome, 1565-1610 (Toronto: Toronto University Press, 2003), which offers an overview of the challenges this period of art has presented to scholars and the typical ways that scholars have dealt with it in the past and Marcia B. Hall, After Raphael: Painting in Central Italy in the Sixteenth Century (Cambridge: Cambridge University Press, 1999), 173-214, which provides a sensitive and careful examination of late-sixteenth-century art in Italy. 
Stylistically, Bitti's Juli paintings are also consistent with his oeuvre. The proportions of the figures are elongated, their poses careful and elegant, and the modeling linear. In the Saint Catherine (Figure 5.4), Bitti covered the female martyr in his trademark crisp drapery, with angular folds that fall independently of the body's volume beneath. Atypical of the Italian's work is the placement of figures within landscape settings; generally Bitti used simple gray or brown backdrops, denying any sense of deep space behind his painted characters. However, the nondescript nature of the landscape setting makes any attempt at interpretation problematic.

2

Juli, Peru

Bitti was one of only three Italian artists known to have arrived in the viceroyalty in the last quarter of the sixteenth century. Mateo Pérez de Alesio (15471628) and Angelino Medoro (1567-1631) were the others. Bitti stands out for his extensive travels in the service of the Jesuits, so while all three Italians impacted later Peruvian painting through followers and students, Bitti's influence was most impactful due to the geographic reach of his career; his paintings dotted the viceregal territory. It is difficult to account for Bitti's reception in Peru, but there is evidence of his continued commissions from the Jesuits. ${ }^{24}$

Juli is a small town in southern Peru, on the banks of Lake Titicaca. The region remained overwhelmingly indigenous well into the eighteenth century due to the law established in the sixteenth century that prohibited any Spaniards (any who were not also missionaries) to settle there. ${ }^{25}$ In the sixteenth century, Juli became the site for one of Viceroy Francisco de Toledo's (1515-82) reducciones (reductions). The reducciones were part of a campaign initiated by the Spanish king to bring order to the region by reorganizing the indigenous populations into towns. Generally this meant consolidating many small villages

Jesse Locker, ed. Art and Reform in the Late Renaissance after Trent (London: Routledge, 2018).

24 Christa Irwin, "Roma in Lima," 27-92; Christa Irwin, "Bernardo Bitti: An Italian Reform Painter in Peru," in Art and Reform in the Late Renaissance after Trent, ed. Jesse Locker (London: Routledge, 2018).

25 Bailey, Andean Hybrid Baroque, 163. The Quechua and the Aymara were the two principal ethnic groups to inhabit the area, the Quechua predominantly to the north and the Aymara to the south. A more detailed descriptions of the region provided by Bailey in the text. 
into several larger towns. ${ }^{26}$ In addition to the governing component of the reduction campaign, Toledo and the Spanish crown had intended for the new organization of the population to ease the integration of mission activities. ${ }^{27}$ Mission groups would be assigned to doctrinas (parishes) around the viceroyalty, which were essentially parishes for the Indians. Priests at each doctrina would assume all of the obligations of stability and monetary privileges that came along with the job; this was an attempt by the crown to establish centralized control over evangelization efforts. ${ }^{28}$

Initially, a group of Dominican friars was assigned to Juli, in 1547. However, after two royal inquiries into their work, and some evidence of dangers and hardships surrounding their activities, Toledo expelled the friars from the region on November 9, 1572, due to what was recorded as abusive and forceful treatment of the people. ${ }^{29}$ Among the missteps was the fact that most of the Dominican friars were not preaching in Aymara, the language spoken by the majority of the population in Juli. ${ }^{30}$ Following the expulsion, Juli was assigned to the Jesuits, but this was not an assignment they initially accepted with easy enthusiasm. The Jesuits had reservations about taking on the responsibilities

26 See Arthur Franklin Zimmerman, Francisco de Toledo: Fifth Viceroy of Toledo, 1569-1581 (New York: Greenwood Press, Publishers, 1968), 122-25 and 260; and Jeremy Ravi Mumford, Vertical Empire: The General Resettlement of Indians in the Colonial Andes (Durham: Duke University Press, 2012), with particular attention to chapter 3, "The Grid," 41-52, for a detailed discussion of the situation of the reducciones.

27 See Sabine MacCormack, "Ancient Authorities Intertwined: Natural Philosophy, History, and Theology in the Writings of José de Acosta," Journal of Jesuit Studies 2, no. 1 (2015): 1-35; Sabine MacCormack “The Heart Has Its Reasons': Predicaments of Missionary Christianity in Early Colonial Peru," Hispanic American Historical Review 65, no. 3 (1985): 443-86, here 453, and Andrés Prieto, Missionary Scientists: Jesuit Science in Spanish South America, 1570-1810 (Nashville: Vanderbilt University, 2011), for further elaboration on the Spanish crown's motivations for instituting the reducciones.

28 Sabine Hyland, The Jesuit and the Incas: The Extraordinary Life of Padre Blas Valera, S.J. (Ann Arbor, MI: University of Michigan Press, 2011), 56-58, Sabine MacCormack, "Grammar and Virtue: The Formulation of a Cultural and Missionary Program by the Jesuits in Early Colonial Peru," in Jesuits II, 576-601, Claudio M. Burgaleta, S.J., José de Acosta, S.J. (1540-16oo): His Life and Thought (Chicago: Loyola Press, 1999), 34-35, Steven J. Stern, Peru's Indian Peoples and the Challenge of Spanish Conquest: Huamanga to 1640 (Madison, WI: University of Wisconsin Press, 1993).

29 Yacin Hehrlein, "La expulsión de la orden dominicana de las doctrinas de Chucuito en 1572: Trasfondo político y económico de una campaña de difamación," in La evangelización del Perú siglos XVI-XVII (Arequipa, Peru: Southern, Peru, 1990), 309-17; Burgaleta, Acosta, 45 .

$30 \quad$ Stanfield-Mazzi, Object and Apparition, 50-51. 
of a doctrina. Ignatius of Loyola (c.1491-1556) had instructed that the order remain connected to their ideals of poverty and mobility; the itinerant style of missionizing practiced by the earliest Jesuits was promoted as the model. The doctrina system would force Jesuits into a single location for an extended period of time. Prior to Juli, despite these concerns, the Jesuits had accepted several doctrina assignments, but the Jesuit Superior General at the time, Francisco de Borja (1510-72), had instructed that they should be limited. ${ }^{31}$ Most recent and proximate to Juli, the Jesuits had worked at Huarochiri, near Lima, but in 1572, the first provincial of Peru, Jerónimo Ruiz de Portillo (c.1532-1590), withdrew because of the vast opposition faced from the indigenous population, which led to the murder of two Jesuits.

When the Jesuits did eventually accept the doctrina at Juli in 1576, the decision was likely related to new leadership: José de Acosta had begun his tenure as second provincial in Peru on January first of that year. ${ }^{32}$ Acosta was one of the most renowned Spanish Jesuits of his time, although many of his ideas were questioned and contested. Acosta advocated for a "theology of adaptation," a philosophy with its origins in humanist thinking. ${ }^{33} \mathrm{He}$ called for missionaries to immerse themselves intellectually and spiritually in the communities where they were attempting to introduce Christianity. The efforts at Juli were led by Acosta's assertion, "First humans and then Christians," a belief that informed all of his work. ${ }^{34}$ In his Natural and Moral History of the Indies, Acosta wrote, "The other aim that can be achieved with knowledge of the laws and customs and polity of the Indians is to help them and rule them by those very laws, for whatever does not contradict the law of Christ and his Holy Church, they

31 Stanfield-Mazzi, Object and Apparition, 34-35. The violence and difficulty at Huarochiri contributed to significant tensions among Jesuit and viceregal leaders. After withdrawing Jesuits from the city, Portillo reportedly refused to serve as Toledo's confessor. Toledo intervened by working with another Jesuit, Diego de Bracamonte who supported the concept of the doctrina, and sent Bracamonte to Rome and Spain to argue his case before the king and the pope.

32 Stanfield-Mazzi, Object and Apparition, 38.

33 Bailey, Jesuit Missions, 42.

34 Burgaleta, Acosta, 48; Luis Martin, "The Peruvian Indian through Jesuit Eyes: The Case of José de Acosta and Pablo Jose de Arriaga," in The Jesuit Tradition in Education and Missions: A 45o-year Perspective, ed. Christopher Chapple (Scranton: University of Scranton Press, 1993), 205-14, here 206-8. Martin explains this more controversial component of Acosta's philosophies, the concept that the Indians were descendants of Adam and Eve just like every other sixteenth-century European. That human tie created the bond and the link that upon which Acosta based his belief in education. 
ought to be governed according to their statutes." ${ }^{35}$ Expressed in this statement is a core value of Acosta's philosophies: there is no particular harm in allowing, and even encouraging, the maintenance of some indigenous rituals and traditions, that a sensitivity to the lives and experiences of those being evangelized would only aid in forming the relationships necessary to successfully preach the Gospel. Acosta's beliefs were put into practice at Juli; documents reveal that the doctrina at Juli was unique among other early colonial parishes in the greater degree of integration with local culture. Several scholars have written about the ceremonies that took place to welcome Acosta on a visit to the city in $1576 .{ }^{36}$ Andean students participated in the festivities, having memorized materials with the help of quipus, the knot records used by the Incas. In a letter written to the Jesuit Superior General Everard Mercurian (1514-80, in office 1573-80), Acosta described one portion of the day:

The schoolboys walked a long way ahead of the rest, singing in their language and in their manner. Next came the men, in great numbers, performing two dances, dressed in silk clothes of Indian style, and dancing in the Spanish manner, and another dance was of some children who hardly knew yet how to walk. Next came their pingullos, or music of flutes, and some twenty-five or thirty crosses with their banners (carried by the heads of ayllus, and then the lords of the village with our fathers. ${ }^{37}$

Acosta's ideas about language had an impact on the daily functioning of the doctrina at Juli. At Juli, the Jesuit missionaries were taught Quechua and Aymara and evangelization was to take place in the language of the converts in order to increase the potential for realistic comprehension. Acosta explained in De procuranda, "Faith comes from hearing, and hearing from the word of God." ${ }^{38}$

Acosta made two visits to Juli, one in ${ }^{1576-77}$ and another in $1578-79$; his time there had an impact. With the implementation of evangelization through the local language, among other tools, Acosta culminated his visits with the positive assertion that the Andeans could be taught in the ways of the Christian faith.

35 José de Acosta, Natural and Moral History of the Indies, ed. Jane E. Mangan (Durham: Duke University Press, 2002), 330.

36 MacCormack, "Grammar and Virtue," 581-82; Hyland, Jesuit and the Incas, 59-6o.

37 MacCormack, "Grammar and Virtue," 582 . MacCormack cites the annual letter written by Acosta to Mercurian on February 15, 1577, M Peru 2, document 26, sec. 72, p. 281.

38 Cited in Burgaleta, Acosta, 46, and MacCormack, "Grammar and Virtue," 583, originally written in Acosta, De procuranda, book 4, chap. 6.1. 
In addition to the lingual and cultural assimilation espoused by Acosta, it is well known that the visual arts were integral to Jesuit missions around the world, and at Peruvian sites like Juli. Art's role in Latin America began even before the arrival of the Jesuits, however. Hernán Cortés $\left(1485^{-1547)}\right.$ is said to have carried works of art with him as he traversed the region, relying on paintings and prints to relay the ideals of the Christian faith. ${ }^{39}$ The necessity of art became more official in 1503 , with a Spanish royal decree initiating the requirement that parishes include a church and holy pictures. ${ }^{40}$ Nine years later, in 1512, the Law of Burgos stated that encomenderos (conquerors who received grants of labor) were required specifically to provide "images of our Lady." In Mexico, Fray Pedro de Gante (1480-1572) founded a school of arts in the chapel of the church at San José so that indigenous craftsmen could be employed in the service of creating the much needed visual objects for the church. ${ }^{41}$ An engraving from the 1579 Rhetórica christiana, written by Diego Valadés (1533-82), provides evidence that by the sixteenth century, preachers were utilizing imagery in their sermons; here the Franciscan friar illustrated points at images on the walls as he speaks from his pulpit to a large crowd of people. ${ }^{42}$

The Jesuits held a respect for the value of the visual arts that seems to have distinguished their efforts from those of other Christian orders of the time. ${ }^{43}$ The order recognized the agency of images in the mission context early in their history; St. Francis Xavier (1506-52) carried engravings, paintings, and small sculptures with him on his travels through India as early as 1542 . In the early 1570s, Jerónimo Nadal (1507-80) composed Evangelicae historiae imagines, an illustrated gospel with captions clearly and legibly explaining the narrative of the images. The Jesuits hired the Wierix brothers of Antwerp to illustrate the

39 Elizabeth Wilder Weisman, Art and Time in Mexico (New York: Harper and Row Publishers, 1985), 33. Weisman describes six small sculptures of the Virgin in wood still known as "Virgen de Cortes."

$40 \quad$ Weisman, Art and Time in Mexico, 33; Bailey, Art on the Jesuit Missions, 35.

41 Weisman, Art and Time in Mexico, 33.

42 Ramon Mujica Pinilla, “" Reading without a Book”: On Sermons, Figurative Art, and Visual Culture in the Viceroyalty of Peru," in The Virgin, Saints, and Angels: South American Paintings 1600-1825 from the Thoma Collection, ed. Suzanne Stratton-Pruitt (Stanford, CA: The Iris and B. Gerald Cantor Center for Visual Arts at Stanford University, 2006), 40-63, here 42.

43 O'Malley et al., Jesuits and the Arts, 10. In the first chapter, O'Malley traces the evolution of the inclusion of culture into the routines and practices of the Jesuits. 
work and after it was published in 1593, brought it with them as they traveled around the world. ${ }^{44}$

In addition to their significant reliance on the visual arts, the Jesuits also came to recognize the need for a great sensitivity to the specific needs and context of commissions. In South America, or anywhere else in the world, they did not promote or impose a particular style of art. ${ }^{45}$ As with language, the Jesuits maintained a policy of adaptation, incorporating regional and indigenous forms into painting, sculpture and, architecture, as well as training and employing local artisans, while also relying on European imports (both in the form of works of art and artists themselves). Tapping into this approach, the Jesuits were able to offer their native audiences visual art built on the principles of European Christian traditions, but tailored to the heritage of the local audience. As the first Jesuit church rose in Cuzco in 1579, Acosta commented,

For the foundations the Andean people have brought ancient cut stone in such quantities that even if the church were to be twice as large, there would be a surplus [...].

Organizing themselves by ayllus or kin groups, to carry the stone to our church and dressing as for a festival with their feather ornaments and adornments they came through the city singing in their language such things as occasion devotion, for instance, "Come brothers, let us bring stones to construct the house of the Lord [...] there they teach us the law of our God and redeemer."46

It is significant to note the Andean involvement in the construction of the church, but also embedded in this narrative is the visual, cultural contribution through the use of what Acosta calls "ancient cut stone." The Inca were expert stoneworkers, their cutting of stone so precise that they famously built massive structures and sound walls without the need for mortar to secure one stone to the next. ${ }^{47}$ In the context of this adaptive practice of artmaking by the Jesuits, what was the function of paintings made by a European artist, like Bitti?

44 William Bangert, Jerome Nadal, S.J., 1507-1580: Tracking the First Generation of Jesuits (Chicago: Loyola University Press, 1992).

45 Gauvin Alexander Bailey, "Jesuit Architecture in Colonial Latin America," in The Cambridge Companion to the Jesuits, ed. Thomas Worcester (Cambridge: Cambridge University Press, 2008), 217-242, here 217; Bailey, “'Le style jesuite n'existe pas': Jesuit Corporate Culture and the Visual Arts," in Jesuits I, 38-89.

46 Cited in Bailey, Art on the Jesuit Missions, 21.

47 Richard L. Burger and Lucy C. Salazar, Machu Picchu: Unveiling the Mystery of the Incas (New Haven: Yale University Press, 2004). 
As scholars continue to hone the precise language necessary to describe and document the production of art from colonial Latin America, there is a need for a more accurate understanding of how artists and patrons intended objects to be received by audiences. The opportunities to better understand the situation that linger are in the examples. Some have taken on this challenge. For example, Clara Bargellini has studied retablos from Jesuit churches in Mexico in order to attempt to assess some commonalities of rationales for choices in subject matter. ${ }^{48}$ She found that the Jesuits commissioned specific works of art to relate to particular devotions in which they were engaged. Similarly, Gauvin Bailey has surveyed style, but also the subject matter of the visual arts produced at the Jesuit reductions of the Guaraní in Paraguay over the seventeenth and eighteenth centuries; he similarly found that the predominance of certain subject matters related to Jesuit preoccupations. ${ }^{49}$ MacCormack and Cohen-Aponte have examined the murals at Andahuaylillas, and the extensive program of conversion instituted in that city. ${ }^{50}$ Bitti's paintings at Juli can similarly further our understanding of how the subject matter and style of art functioned on the Jesuit missions. Ultimately, Juli may not be unique; I suspect that Bitti's contributions at this town's churches are much like the contributions of other European artists at many other Andean towns from this time. Juli's history is well-studied and fairly well-documented and therefore is a handy starting point for the conversation.

Close analysis of the subject matter and iconography of Bitti's Juli paintings, with a consideration of their context, can yield a better understanding of the work. Bitti's paintings have never been given this attention in the past. Scholarship on Bitti has largely been superficial, offering his work and the artist the difficult and problematic title of "Mannerist" and neglecting to consider the import of the works' subject matter in their context. These are not hybrid paintings. They are paintings made by an Italian, but they were seen by an audience of largely indigenous Andeans, new converts to Christianity. ${ }^{51}$ Some

48 Clara Bargellini, "Jesuit Devotions and retablos in New Spain," in Jesuits I, 680-98.

49 Bailey, Art on the Jesuit Missions, 169. This section includes a condensed discussion of an inventory of subject matter of sculptures at the sites studied.

5o Sabine MacCormack, "Art in a Missionary Context: Images from Europe and the Andes in the Church of Andahuaylillas near Cuzco," in The Word Made Image: Religion, Art, and Architecture in Spain and Spanish America, 1500-160o (Boston: Isabella Stewart Gardner Museum, 1998), 103-21, and Ananda Cohen-Aponte, "Painting Andean Liminalities at the Church of Andahuaylillas, Cuzco, Peru," Colonial Latin American Review 22, no. 3 (2013): 369-99.

$5^{1}$ See Dean and Leibsohn, "Hybridity and Its Discontents," for a thorough discussion of the complications of the word "hybrid" in this context. See also Robert Young, Colonial Desire: Hybridity, in Theory, Culture, and Race (London: Routledge, 2010). 
consideration of their subject matter in the context of the town of Juli is meant to offer meaning to these works.

Ultimately, there is little that is unusual about the iconography of Bitti's paintings in general. They follow European prototypes, which is exactly what Bitti offered viceregal painting, a knowledge of Christian iconography and European style. ${ }^{52}$ Just as the Spanish built European cities in Mexico and South America to assert Old World presence, European paintings lining the walls of newly built Peruvian churches served as constant reminders of the foreign continent's cultural presence.

In Lima, several decades prior to Bitti's time in Juli, Fray Bracamonte had requested from Rome a skilled painter, to offer "images that represent with majesty and beauty what they signify, because the people of this nation are led by such things." ${ }^{53}$ Bitti was the artist delivered in response. In the Peruvian chronicler, Francisco de Echave y Assu's seventeenth-century description of paintings and sculptures that decorated Lima's cathedral for the celebration of the viceroyalty's second canonized saint, Toribio Alfonso de Mogrovejo (1538-16o6), is evidence of the rich display of large images of saints and martyrs that were made by European painters like Bitti. Thomas Cummins indicates that the chronicler focused on the realistic representation of Christian characters, a Saint Paul so close to life that his voice could almost be heard, and a scene of St. Lawrence's martyrdom so real that his anguished cries were almost audible. These comments are familiar to readers of fifteenth- and sixteenthcentury Italian commentaries on art, commending artists such as Donatello for the creation of "speaking likeness" in sculptures. The so-called Renaissance brought with it an interest in art works that made objects, and the biblical characters they portrayed, come to life for their viewers. Cummins explains that the visceral response of viewers was critical, but also that viewers were expected, from teaching and sermons, to understand how to read and react to these paintings, which Echave y Assu is careful to note, have all been sent from Rome. ${ }^{54}$

52 Joseph J. Rishel, Arts in Latin America (Philadelphia: Philadelphia Museum of Art, 2006), 416-17. See Marcus Burke's essay about the parallel course of European and Latin American painting and the catalogue entry for Bernardo Bitti's Madonna of the Expectation and Angelino Medoro's Deposition.

53 Francisco Matos, ed., Historia general de la Compañía de Jesús en la provincia del Perù, 1600 (Madrid: Instituto Gonzalo Fernández de Oviedo, 1954), 245; also cited in Thomas Cummins, "Images for a New World," in The Virgin, Saints, and Angels: South American Paintings 1600-1825 from the Thoma Collection, ed. Suzanne Stratton-Pruitt (Stanford, CA: The Iris and B. Gerald Cantor Center for Visual Arts at Stanford University, 2006), 2-28, here 14 .

Cummins, "Images for a New World," 16. 
What follows is a brief attempt to consider an analysis of Bitti's Juli paintings in their Juli context, as tools used by the Jesuits in the efforts to spread Christianity. The Holy Family is traditional in many senses, taking the symbolism of the Virgin handing a pear to the young Christ Child from European examples, most commonly those of northern Europe. Albrecht Dürer's (1471-1528) 1511 engraving is closest in conception to Bitti, in the way that the Child is presented not as docile and playful, but confident and in control, even taking his small hand to the chin of his mother as if to direct her attention. ${ }^{55}$ It is likely that Bitti could have seen the original print by Dürer or a copy; indeed many of the German master's prints were brought to Mexico and Peru. Moreover Dürer's

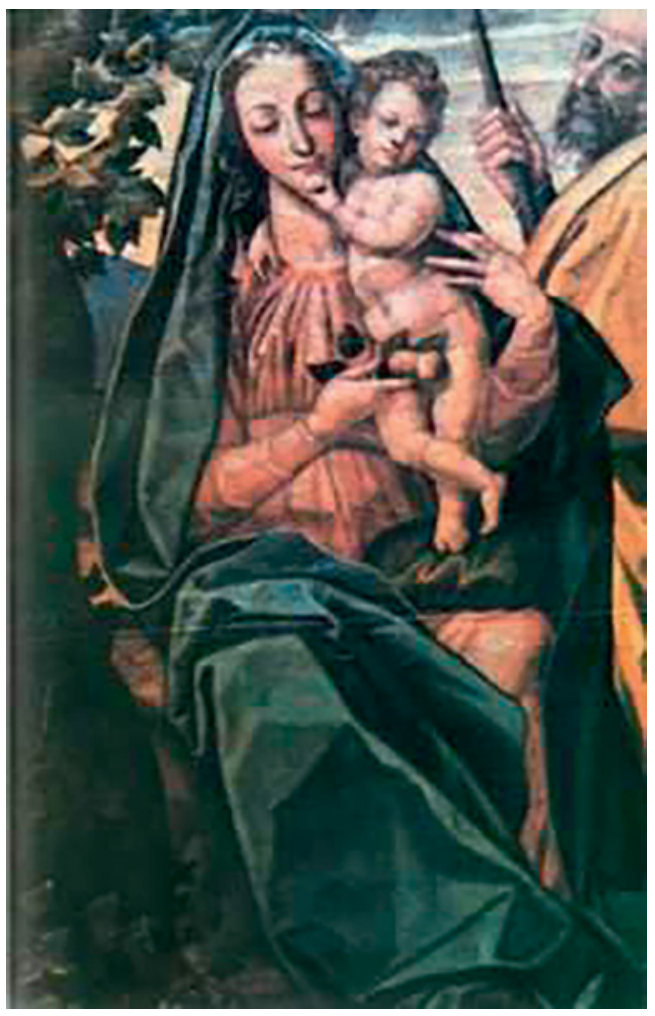

FIGURE 5.1 Bernardo Bitti, Holy Family, 1585-1602, Church of Saint Peter, Juli, Peru, oil on panel PHOTO IN PUBLIC DOMAIN

55 Ellen Jacobowitz, "The Virgin and the Child with the Pear, 1511, by Albrecht Dürer" Philadelphia Museum of Art Bulletin 80, nos. 343/344 (Summer/Autumn 1984): 14-15. Erwin Panofsky, The Life and Work of Albrecht Durer (Princeton: Princeton University Press, 1955), 150, also makes mention of the print. 
engraving was also copied by others, including Hieronymus Wierix (1553-1619), so the composition would have been widely available.

The only somewhat unusual component to this painting is Bitti's combination of a traditional Madonna and Child theme with a scene that includes the entire Holy Family, by adding Joseph. While unusual in a sixteenth-century European context, Joseph's inclusion is not at all uncommon in Latin American paintings of the time. Charlene Villaseñor Black surveyed the ascendance of images of St. Joseph in Spain and Mexico through the sixteenth and seventeenth centuries, used as representations of gender ideals, and even more, St. Joseph representing the protector of the Spanish empire; he had been named patron of the Conquest in 1555 and in 1679, King Charles II of Spain (r.1665-1700) designated Joseph patron of the Spanish kingdom. ${ }^{56}$ Bitti's painting represents an example of a transition in the history of European paintings from the Middles Ages and early Renaissance when the artist routinely relegated Christ's foster father to the background of the painting, wholly displaced and distracted from the interaction of mother and child. In Bitti's painting, Joseph does not yet actively engage with the group, as he will in later examples, but the artist pushed him into the foreground, and turned his head to allow a gaze directly out at the viewer. According to Villaseñor Black's careful study, the uncommon fusion of subject matter, a scene that was generally dedicated to mother and child alone with the added presence of Joseph to make it a Holy Family, is also typical. ${ }^{57}$ As artists transitioned Joseph from the shadowy old man in the back to a present, strong, and loving father, they experimented with a variety of subjects. The experimental nature of Bitti's painting, and all those others of the late sixteenth century may be explained by the contemporary theological debates surrounding Joseph's age and appearance; the church itself was in the midst of deciding how to handle the emerging importance of Joseph.

Like all other inclusions of Joseph in colonial Latin America and Spain through the early modern period, this painting was likely intended to promote Joseph's role as protector of the Spanish empire, and to utilize the saint as an exemplar of masculine behavior, the ideal husband and father of the nuclear

56 Charlene Villaseñor Black, Creating the Cult of St. Joseph: Art and Gender in the Spanish Empire (Princeton: Princeton University Press, 2006). St. Joseph's rising prominence in art has also been studied in the following studies: Joseph F. Chorpenning, O.S.F.S., The Holy Family as Prototype of the Civilization of Love (Philadelphia: St. Joseph's University Press) and Carolyn C. Wilson, St. Joseph in Italian Society and Art-New Directions and Interpretations (Philadelphia: St. Joseph's University Press, 2001).

Villaseñor Black, Cult of St. Joseph, 62. 
family. ${ }^{58}$ Considering the painting in its context, this interpretation becomes richer. Among the goals laid out by the Jesuits at Juli was the eradication of traditions and practices considered contrary to Christianity, with concubinage at the top of that list. ${ }^{59}$ The European ideal of a nuclear family was also a standard goal; when the Jesuits initially arrived they pardoned individuals living together out of wedlock, providing they confessed and later married. ${ }^{60}$

Likewise, Bitti's Baptism of Christ and Saint John the Baptist can be understood as responses to local needs, namely the significance of baptism as a sign of spiritual conversion and acceptance. Baptism marked the first symbolic step in the spiritual conquest of Peru. To the Jesuits, it marked a promise of participation and commitment. The goal of missionaries to foreign lands was to baptize the indigenous populations; counts of baptized were kept, Libros de bautismos (log books of baptisms) were maintained, and as the numbers rose, the success of evangelization was at hand. Almost immediately upon arrival in Juli, the first seven Jesuits gathered the town in a massive service, where they baptized a large group of locals. Visual representations of baptism offered didactic opportunities to make the sermons real and tangible. ${ }^{61}$ All mission churches included an image of St. John the Baptist; in his 1577 proceedings of the Council of Trent, Charles Borromeo (1538-84) had prescribed that an image of the Baptist adorn every baptistery. ${ }^{62}$ Ananda Cohen-Aponte recently articulated the particular agency of baptism imagery in colonial art. ${ }^{63}$ As the rite of admission into the faith, baptism marked the shift from pagan to Christian. Comprehension and acceptance of the ritual was vital. Visual representations

58 Villaseñor Black, Cult of St. Joseph.

59 Scholars have begun to study the sociology of the family in colonial Latin American and gathered statistics about instances of concubinage, marriage, and relationships. Thomas Calvo, "The Warmth of the Hearth: Seventeenth-Century Guadalajara Families," in Sexuality and Marriage in Colonial Latin America (Lincoln: University of Nebraska, 1989), 287312 , reviews some of these issues generally and in the context specifically of Guadalajara.

6o The nuclear family became of particular significance in Europe over the course of the sixteenth century as focus on kin groups fell out of favor, and interest in a lead father figure took its place. Steven E. Ozment, When Fathers Ruled: Family Life in Reformation Europe (Cambridge, MA: Harvard University Press, 1983) and Lawrence Stone, "The Rise of the Nuclear Family in Early Modern England: The Patriarchal Stage," in The Family in History, Lectures Given in Memory of Stephen Allen Kaplan under the Auspices of the Department of History at the University of Pennsylvania (Philadelphia: University of Pennsylvania Press, 1975), 13-58, are good sources.

$61 \quad$ Hyland, The Jesuit and the Incas, 59.

62 Clara Bargellini and Michael Komanecky, The Art of the Missions of Northern New Spain, 16oo-1821 (Mexico City: Antiguo Colegio de San Ildefonso, 2009), 265.

63 Ananda Cohen-Suarez, "From the Jordan River to Lake Titicaca: Paintings of the Baptism of Christ in Colonial Andean Churches," Americas 72, no. 1 (2015): 103-8. 


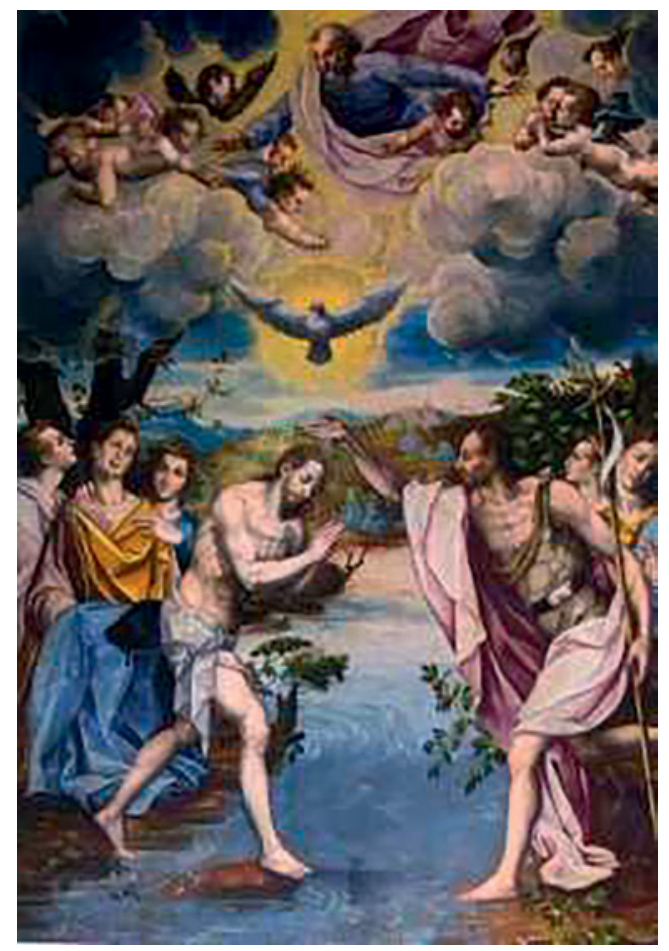

FIGURE 5.2 Bernardo Bitti, Baptism of Christ, 1585-1602, Church of Saint John the Baptist, Juli, Peru, oil on panel PHOTO IN PUBLIC DOMAIN

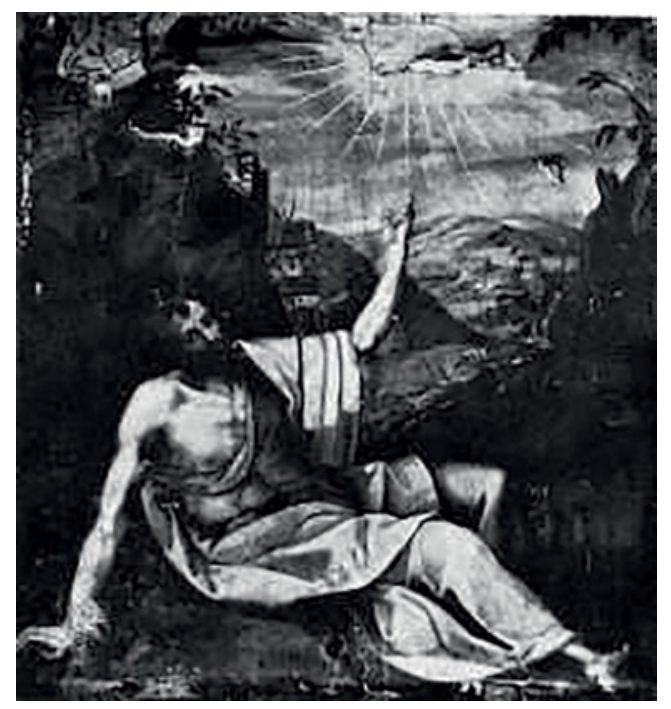

FIGURE 5.3 Bernardo Bitti, Saint John the Baptist, 1585-1602, Church of Saint Peter, Juli, Peru, oil on panel PHOTO IN PUBLIC DOMAIN 
offered didactic opportunities to make the sermons of priests and friars real and tangible.

The Baptism of Christ is striking in Bitti's oeuvre for the complexity of its composition and the inclusion of detailed landscape. The majority of Bitti's paintings feature one or two figures, pressed close to the picture plane, with little to no background, and limited attributes. Although, a few recently published paintings from the church of Santo Tomás de Aquino de Rondocan are similarly spatially complex. ${ }^{64} \mathrm{~A}$ likely source for the Juli Baptism is an engraving by the Flemish printmaker, Pieter Perret $\left(1555^{-1625}\right)$, after a work by Bitti's fellow Italian transplant, Mateo Pérez de Alesio who painted the original for the high altar of Saint John's Cathedral in Valletta, Malta. ${ }^{65}$ There is, however, great distance between Malta and Juli. Alesio worked for the Maltese Grand Master for several years in the late 1570 s, prior to his arrival in Lima. Alesio commissioned Perret to produce a series of engravings based on the extensive program of murals he produced in the reception room of the city's great palace. ${ }^{66}$ Alesio brought books and prints with him on the journey to Peru, and these engravings after his own work must have been among the others. ${ }^{67}$ The type of Baptism represented in Perret's print is centrally composed around the water of baptism, aligned with the dove of the Holy Spirit and a hovering figure of God the Father, with Christ and John the Baptist to either side of the composition. There are some departures in Bitti's painting; the flanking figures are no longer designated angels, with wings, but instead are bystanders, Bitti has increased the amount of landscape, and reduced the number of figures.

Bitti's painting of St. John the Baptist is reminiscent of European representations of John in the wilderness, a reference to his hermit-like state of living, dressed in his prototypical simple clothing and fur shirt, disheveled hair, and

64 Ananda Cohen Suarez, Paintings of Colonial Cusco: Artistic Splendor in the Andes (Cusco, Peru: Haynanka Ediciones S.A.C., 2015). The Rondocan paintings have not been studied at all and deserve attention and analysis due to their striking differences from most other paintings in Bitti's oeuvre.

65 Cohen-Suarez, "Paintings of the Baptism of Christ," 112-17. Bitti's was the first of the subject in this region, after which many others were made, suggesting that his painting and/ or the print may have had a significant impact.

66 Lucio Maiorano, Matteo Pérez d'Aleccio: Pittore ufficiale del grande assedio di Malta (Lecce: Lupo, 2000).

67 Antonio Palesati and Nicoletta Lepri, Matteo da Leccia: Manierista toscano dall'Europa al Peru (Pomarance: Associazione Turistica "Pro Pomarance," 1999). Palesati and Lepri make note of Alesio's collection of books and prints, including those by Dürer, that he carried with him across the ocean, but do not mention Perret's engravings. I am making a likely assumption here. 
lack of finery. There are plenty of European examples that show John reclining in a landscape, pointing to his divine inspiration, generally a dove representing the Holy Spirit; Bitti's use of the lamb as the object of John's attention, illuminated in the sky, is atypical, and perhaps included here to make a direct correlation between the Baptist and Christ.

The final two extant paintings by Bitti depict female martyrs: St. Catherine of Alexandria and St. Margaret. Both saints of early Christian origins, their inclusion here can be related to Counter-Reformation trends that encouraged representations of the church's first saints and martyrs, drawing on ancient history and creating a lineage that connected to the sixteenth-century present. ${ }^{68}$ Therefore, like Bitti's other paintings, these two perfectly suited the needs and expectations of the post-Tridentine climate. Bitti responded to those needs repeatedly over the course of his career. However, there may be a deeper, more

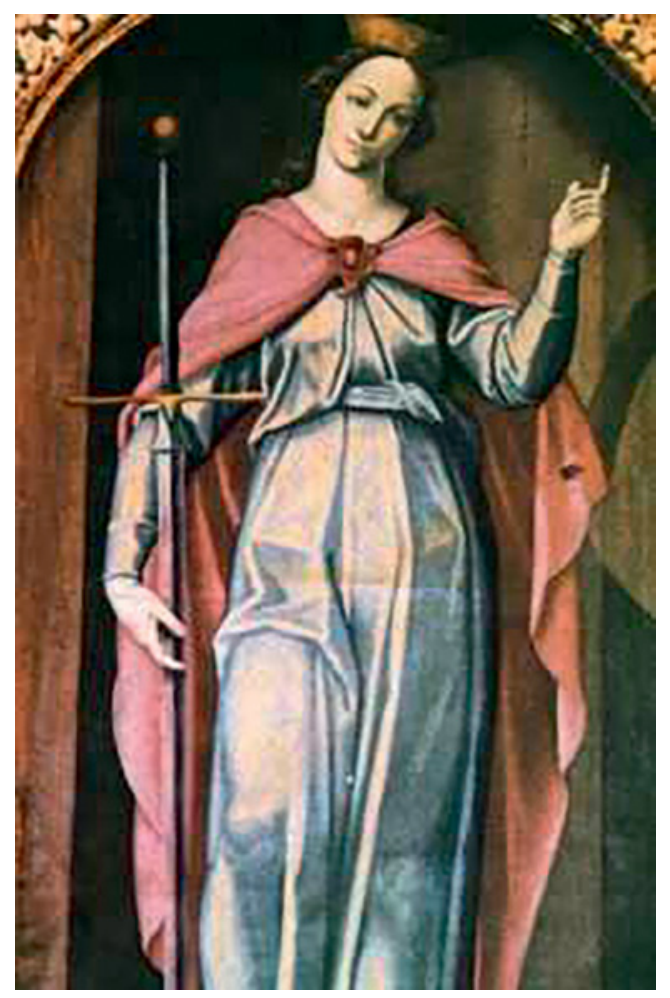

FIGURE 5.4 Bernardo Bitti, Saint Catherine, 1585-1602, Church of Saint Peter, Juli, Peru, oil on panel PHOTO IN PUBLIC DOMAIN

68 Bailey, "Creating a Global Artistic Language," 226-48. 
specific meaning to the inclusion of early Christian saints at the Juli churches. Alonso de Barzana (1530-97) was one Jesuit to arrive in the early years of the mission, having traveled to Lake Titicaca from Cuzco, in 1577 with Blas Valera, a mestizo Jesuit priest known to have been beloved by the local populations. ${ }^{69}$ Like all Christian missionaries, Barzana's goal was to convert the indigenous people of the region. What distinguished Barzana somewhat was his singular focus on the need to convert people the world over. The evangelization of the Andean populations was just one part of a global effort to Christianize all living people. Motivating this campaign was the widely held belief that a worldwide population that had received Christianity would bring the second coming of Christ. ${ }^{70}$ Barzana understood the spread of the Spanish and Portuguese empires as a sign that the world would end. He referred the indigenous people of the Andes "American gentiles" and saw the opportunity to convert them as akin to the efforts made by the apostles to spread Christianity in the early days of the faith. ${ }^{71}$ Barzana, and others including Blas Valera, anticipated and attempted to orchestrate intellectual conversations with native leaders about faith and God, much like the debates that took place among the early church fathers and the Greek gentiles. In this context, then, Catherine may have seemed an apt representative of those early days of conversion in the Christian church. She was heralded as a brilliant speaker capable of converting even the least willing, her life's goal, much like that of the Jesuits, to convert those following pagan faiths. In Europe, Catherine was most commonly represented with the wheel, used as part of her torture, and the martyr's palm. Less common is the inclusion of the sword, shown here, used to behead the young saint, ordered by the Roman emperor Maxentius. The sword here, though, serves as a powerful reference to the fall of the pagan past, and the ascension of Christianity.

Bernardo Bitti's participation at the Jesuit mission site of Juli in the latesixteenth century offers a rich opportunity to examine the calculated meeting of European culture and indigenous heritage in colonial Peru. In a city so rich in Andean culture, where traditional dances, local language and art persisted, the Jesuits imported Bernardo Bitti as a tool in their program of evangelization, his paintings becoming instruments in their conversion campaign. Drawing on the belief that the illusionistic art of the European Renaissance could

69 Hyland, Jesuit and the Incas, 56.

70 Hyland, Jesuit and the Incas, 53.

71 Hyland, Jesuit and the Incas, 54. 
persuade and convert, Bitti's paintings hung in Juli's churches likely with the aim to inspire. Further, the Jesuits utilized these paintings as carriers of Christian messages. Here, it is compelling to further question their role, as arbiters of appropriate style and documents of Christian morals and doctrine in their subject matter. 